\title{
The Genetic Heterogeneity of Lactic Acidosis: Occurrence of Recognizable Inborn Errors of Metabolism in a Pediatric Population with Lactic Acidosis
}

\author{
B. H. ROBINSON, ${ }^{(41)}$ J. TAYLOR, and W. G. SHERWOOD \\ Departments of Paediatrics and Biochemistry, University of Toronto, and Research Institute, The Hospital for Sick
}

Children, Toronto, Ontario, Canada

\begin{abstract}
Summary
A total of $\mathbf{4 0}$ skin fibroblast cultures from pediatric cases of lactic acidosis were subjected to a series of tests designed to elucidate the nature of an underlying defect in metabolism. Of these $\mathbf{4 0}$ cases, in 14 we were able to define the following problems. Pyruvate carboxylase deficiency was evident in five cases showing $<10 \%$ normal activity. Phosphoenolpyruvate carboxykinase deficiency was evident in one case where the whole cells showed $17 \%$ of normal activity whereas the mitochondrial activity of this enzyme was $6 \%$ of normal. Pyruvate dehydrogenase deficiency was present in six cases showing 8 to 39\% of normal activity, five of them being due to deficient pyruvate decarboxylase activity and one of them being due to deficient dihydrolipoyl dehydrogenase activity. Two cases were found with normal enzymes of pyruvate metabolism in which the production of ${ }^{14} \mathrm{CO}_{2}$ from $\left[3-{ }^{14} \mathrm{C}\right.$ pyruvate was deficient at 13 and $28 \%$ of normal activity, respectively, which we consider to be indicative of reduced activity of the Krebs' cycle. The grounds for the diagnosis of these 14 affected cases are documented, and the clinical presentation of these enzyme deficiencies is assessed in the light of present knowledge about lactic acidosis.
\end{abstract}

\section{Speculation}

We speculate that the continuing use of the comprehensive diagnostic approach to pediatric cases of lacticacidosis as set out in this manuscript will eventually reveal the incidence, character, and clinical manifestations peculiar to the various enzyme deficiencies which collectively contribute to this syndrome.

Hereditary enzyme deficiencies leading to lactic acidosis have been demonstrated in two main areas: in the enzymes of the pyruvate dehydrogenase complex and in the key enzymes of the pathway of gluconeogenesis. The total pyruvate dehydrogenase complex contains six enzyme protein components: the catalytic sequence is composed of pyruvate decarboxylase $\left(E_{1}\right)$ an $\alpha_{2} \beta_{2}$ tetramer, dihydrolipoyl transacetylase, and dihydrolipoyl dehydrogenase $\left(E_{3}\right)$, although there is a specific kinase and a phosphatase modulating the activity of $E_{1}(9,26,37)$. At least nine confirmed cases of $E_{1}$ deficiency have been described $(3,5,6,11$, 12. 30). A presumptive, but unproven, diagnosis of dihydrolipoyl transacetylase deficiency has been made (8), and two cases of $E_{3}$ deficiency have been described $(14,25)$. We have previously described a case of a specific pyruvate dehydrogenase phosphatase deficiency (24). A specific kinase deficiency remains undescribed but presumably would not present with lacticacidosis.

Deficiencies of the gluconeogenic enzymes have been described usually associated with both lactic acidosis and hypoglycemia. Deficiencies of glucose-6-phosphatase $(16,17)$ and fructose-1,6diphosphatase $(20,21)$ have been recognized for a number of years, the diagnosis being made most commonly on measurement of enzyme activity on a liver biopsy specimen. Where phosphoenolpyruvate carboxykinase (PEPCK) and pyruvate carboxylase deficiencies are concerned, the number of cases are few, and the associated symptoms not always similar. Two diagnoses have been made based on the measurement of pyruvate carboxylase activity in fibroblasts $(1,10)$; in other cases, the diagnosis has been made on liver biopsy $(29,31,33,35)$. Three cases of PEPCK deficiency have been documented, in two of which the localization of the defect is not specified $(13,15)$, and in one of which the cytosolic PEPCK is identified as the missing component (36).

Fatal lactic acidosis has been described in which postmortem examination of muscle tissue showed in one case deficient cytochrome $a a_{3}$ and cytochrome $b(34)$, and in another case, deficient cytochrome $a a_{3}(38)$. In both cases, the defect seemed to be confined to skeletal muscle.

We present here the results of our studies on the skin fibroblasts from 40 new patients with lactic acidosis and attempt to correlate identifiable metabolic deficiencies with clinical presentation.

\section{MATERIALS AND METHODS}

\section{CHEMICALS}

${ }^{14} \mathrm{C}$-Labeled pyruvate, glucose, leucine, and valine were obtained from Amersham Corp., Ltd. (Oakville, Canada). $\left[1-{ }^{14} \mathrm{C}\right] \alpha-$ Ketoglutarate was obtained from New England Nuclear (Lachine, Quebec, Canada), and $\mathrm{L}\left[1-1{ }^{14} \mathrm{C}\right]$ isoleucine was obtained from $\mathrm{Cal}$ atomic (Los Angeles, CA). L-aminoacid oxidase, catalase, and citrate synthase were obtained from Boehringer Mannheim, (St. Laurent, Quebec, Canada). Other biochemicals were from Sigma Chemical Co. (St. Louis, MO).

\section{CULTURED FIBROBLASTS}

Explants were grown from forearm skin biopsies taken with informed parental consent in Eagle's medium at $37^{\circ} \mathrm{C}$ with $15 \%$ fetal calf serum added. Confluent cells were harvested with $0.025 \%$ trypsin. Cells used for studies were washed free of trypsin by repeated $(\times 3)$ centrifugation and resuspension of the packed cells in phosphate-buffered saline.

\section{WHOLE-CELL ASSAYS}

Aliquots ( 150 to $600 \mu \mathrm{g}$ cell protein) of trypsinized fibroblasts were added to $1 \mathrm{ml} \mathrm{Kreb's} \mathrm{phosphate} \mathrm{buffer} \mathrm{with} \mathrm{the} \mathrm{radiolabeled}$ substrate contained in $25 \mathrm{ml}$ Erlenmeyer flasks. The flasks were capped, and ${ }^{14} \mathrm{CO}_{2}$ was collected on hyamine soaked $(0.2 \mathrm{ml})$ filter paper inserts held in plastic wells attached to rubber stoppers. After the reaction period $(90 \mathrm{~min})$, the reaction was terminated by the addition of $1 \mathrm{ml} 0.08 \mathrm{M}$ citric acid, and a further $35-\mathrm{min}$ collection period followed. The filter inserts were removed with 
forceps and placed in $10 \mathrm{ml}$ toluene ethanol $(9: 1 \mathrm{v} / \mathrm{v})$ scintillation fluid with $0.5 \%$ 2,5-diphenyloxazole, and $0.03 \%$ 1,4-bis[2-(5-phenyloxazoylyl)]benzene added. The ${ }^{14} \mathrm{C}$ activity was counted via Beckman LS-355 liquid scintillation spectrometer. Appropriate control incubations were conducted for such experiment to account for nonenzymatic ${ }^{14} \mathrm{CO}_{2}$ production, and all incubations were performed in duplicate. Pyruvate oxidation rates were determined using a concentration of $0.5 \mathrm{mM}$ pyruvate with $0.35 \mu \mathrm{Ci}$ of $\left[1-{ }^{14} \mathrm{C}\right]$ pyruvate or $\left[3-{ }^{14} \mathrm{C}\right]$ pyruvate added per flask. Branchedchain amino acid oxidation was studied using a concentration of $0.5 \mathrm{mM}$ leucine with $0.5 \mu \mathrm{Ci}\left[1-{ }^{14} \mathrm{C}\right]$ leucine added per flask. $\alpha$ Ketoisocaproate oxidation was studied at a concentration of 100 $\mu \mathrm{M}$ with $0.2 \mu \mathrm{Ci}\left[1-{ }^{14} \mathrm{C}\right] \alpha$-ketoisocaproate added per flask.

\section{PYRUVATE DEHYDROGENASE-TOTAL COMPLEX}

This was carried out by a modification of the method of Taylor et al. (33). Trypsinized washed cells ( $1 \mathrm{mg}$ protein) were suspended in $0.8 \mathrm{ml}$ of a buffer containing $10 \mathrm{mM}$ phosphate, $1 \mathrm{mM}$ EDTA, $1 \mathrm{mM}$ dithiothreitol, and $1 \%$ fatty acid-free bovine serum albumin (pH 7.4). The cells were then disrupted by sonication $(2 \times 10 \mathrm{sec}$ on $30 \%$ power output of Artek Ultrasonic Dismembrator). Fifty $g$ cell protein were added to $0.2 \mathrm{ml}$ of a buffer of the same composition as above, but containing in addition $2 \mathrm{mM} \mathrm{MgCl}, 0.15 \mathrm{mM}$ CoASH, $1.6 \mathrm{mM}$ NAD, $0.1 \mathrm{mM}$ TPP, $0.25 \mathrm{mM}$ pyruvate, and 0.25 $\mu \mathrm{Ci} / \mathrm{ml}\left[1-{ }^{14} \mathrm{C}\right]$ pyruvate. The reaction volume was contained in a small plastic tube lodged in $25 \mathrm{ml}$ Erlenmeyer flasks, and the flasks were carefully sealed by rubber stoppers filled with plastic well containing $0.2 \mathrm{ml}$ hyamine hydroxide. After $45 \mathrm{~min}$ incubation at $37^{\circ} \mathrm{C}$, the hyamine was removed by syringe from each plastic well, the well was washed with $0.4 \mathrm{ml}$ ethanol, and they hyamine and ethanol were added to $10 \mathrm{ml}$ toluene:ethanol $(9: 1)$ scintillation mixture described above. For total pyruvate dehydrogenase, $\mathrm{Mg}^{2+}(10 \mathrm{mM})$ and $\mathrm{Ca}^{2+}(10 \mathrm{mM})$ were added to ensure that the enzyme was fully activated. Controls with no cell protein or acid denatured cell protein were run simultaneously to account for nonenzymatic ${ }^{14} \mathrm{CO}_{2}$ production. Inclusion of an acidification step gave no further increase in the yields of ${ }^{14} \mathrm{CO}_{2}$ using this method.

\section{PYRUVATE DEHYDROGENASE E}

This was measured by slight modification of the technique described by Blass et al. (3). Assay volumes were reduced from 1.0 to $0.2 \mathrm{ml}, 100 \mu \mathrm{m}$ cell protein was added to each incubation for decarboxylase determination, and ${ }^{14} \mathrm{CO}_{2}$ was collected in hyamine rather than sodium hydroxide.

\section{PYRUVATE DEHYDROGENASE $E_{3}$}

This was measured by two methods. In the direction lipoamide to reduced lipoamide, the modified method of Reed and Wilms (22) was used. Sonicated trypsinized and washed fibroblasts (50 to $300 \mu \mathrm{g}$ cell protein) were added to identical cuvettes containing 1 $\mathrm{ml} 0.15 \mathrm{M}$ phosphate buffer $(\mathrm{pH} 8.1) 0.2 \mathrm{mM} \mathrm{NADH}$ at $37^{\circ} \mathrm{C}$. The decrease in absorbance from a steady state was measured at $340 \mathrm{nM}$ in a split-beam spectrophotometer (Pye Unicam SP 1800) on addition of $2.5 \mathrm{mM}$ lipoamide to the test cuvette. In the opposite direction, the method of Melancon et al. (19) was used at pH 7.8.

\section{2-OXOGLUTARATE DEHYDROGENASE}

This was measured exactly as for pyruvate dehydrogenase total active complex except that 2 -oxoglutarate and $2-\left[1-{ }^{14} \mathrm{C}\right]$ oxoglutarate were used instead of pyruvate and $\left[1-{ }^{14} \mathrm{C}\right]$ pyruvate.

\section{2-OXOGLUTARATE DECARBOXYLASE}

This was measured exactly as for pyruvate decarboxylase except that 2-oxoglutarate and $2-\left[1-{ }^{14} \mathrm{C}\right]$ oxoglutarate were used instead of pyruvate and $\left[1-{ }^{14} \mathrm{C}\right]$ pyruvate.

\section{BRANCHED-CHAIN KETO ACID DEHYDROGENASE}

This was measured as for pyruvate dehydrogenase except that $1-{ }^{14} \mathrm{C}$-labeled $\alpha$-ketoisovalerate was used as substrate instead of $\left[1-{ }^{14} \mathrm{C}\right]$ pyruvate. $1-{ }^{14} \mathrm{C}$-Labeled branched chain keto-acids were prepared from the corresponding branched chain amino acids by the method of Rudiger et al. (28).

\section{PYRUVATE CARBOXYLASE}

Pyruvate carboxylase was measured by the method of Atkin et al. (1) modified such that the specific activity of $\mathrm{NaH}^{14} \mathrm{CO}_{3}$ was 10 times higher at $1 \mathrm{mCi} / \mathrm{mmole}$, and the cells were disrupted by sonication rather than freeze-thawing. This latter modification was found to be a faster method than freeze-thawing because there was no difference in enzyme activity measured after either treatment.

\section{PEPCK}

This was assayed by two methods. In the direction of phosphoenolpyruvate formation, the method of Roobol and Alleyne (27) was used with a minor modification in that the rate of reduction of NAD was monitored fluorimetrically to give greater sensitivity and that $0.05 \%$ Triton $\mathrm{X}-100$ was included in the incubation medium to disrupt the added mitochondria or fibroblasts. In the direction of oxoloacetate formation, the method of Ballard and Hanson (2) was used again in the presence of Triton X-100 $(0.05 \%)$ to disrupt either mitochondria or fibroblasts. All of the above assays were carefully monitored in time courses, and the times selected for the running of each assay were in the linear portion of the progress curve for the reaction.

\section{PATIENT MATERIAL}

Fibroblasts were accepted for study if the patient's presentation met with certain criteria. (1) The patient must have a demonstrable lacticacidemia on a chronic or episodic basis with blood lactate values $>2 \mathrm{mM}$. (2) There must be no evidence of primary cardiorespiratory or liver disease or metabolic alkalosis. Clinical tests should have ruled out glucose-6-phosphatase and fructose-1,6diphosphatase deficiency. (3) Analysis of urine organic acids should reveal no abnormal accumulation of organic acids other than lactate:pyruvate,3-hydroxybutyrate, and acetoacetate.

\section{INVESTIGATION OF PYRUVATE METABOLISM IN FIBROBLASTS}

There are, as we described in the introduction, a number of possible areas in which an enzyme deficiency could lead to lactic acidosis. These areas can be roughly divided into the pathway of gluconeogenesis, the behavior of the pyruvate dehydrogenase complex, and the operation of the Krebs' cycle and cytochrome system (Fig. 1).

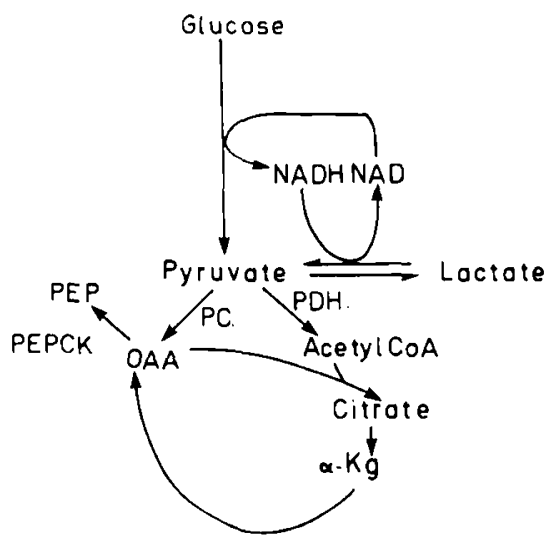

Fig. 1. Reactions involved in the production and utilization of pyruvic and lactic acids. Key enzymes denoted are pyruvate dehydrogenase $(P D H)$, pyruvate carboxylase $(P C)$, and PEPCK. 
Because we asked that glucose-6-phosphatase and fructose-1,6phosphatase deficiency be ruled out clinically before we started fibroblast investigations, this meant that in the area of gluconeogenesis we were looking at the activities of pyruvate carboxylase and PEPCK. It has been reported that the PEPCK in fibroblasts is almost exclusively mitochondrial (1), so this means in effect that out tests would not exclude cytosolic PEPCK deficiency. Thus only part of the gluconeogenic pathway is present in fibroblasts. All cell lines were assayed for pyruvate carboxylase and PEPCK activities.

FLow Chart for TESTIME CELLS

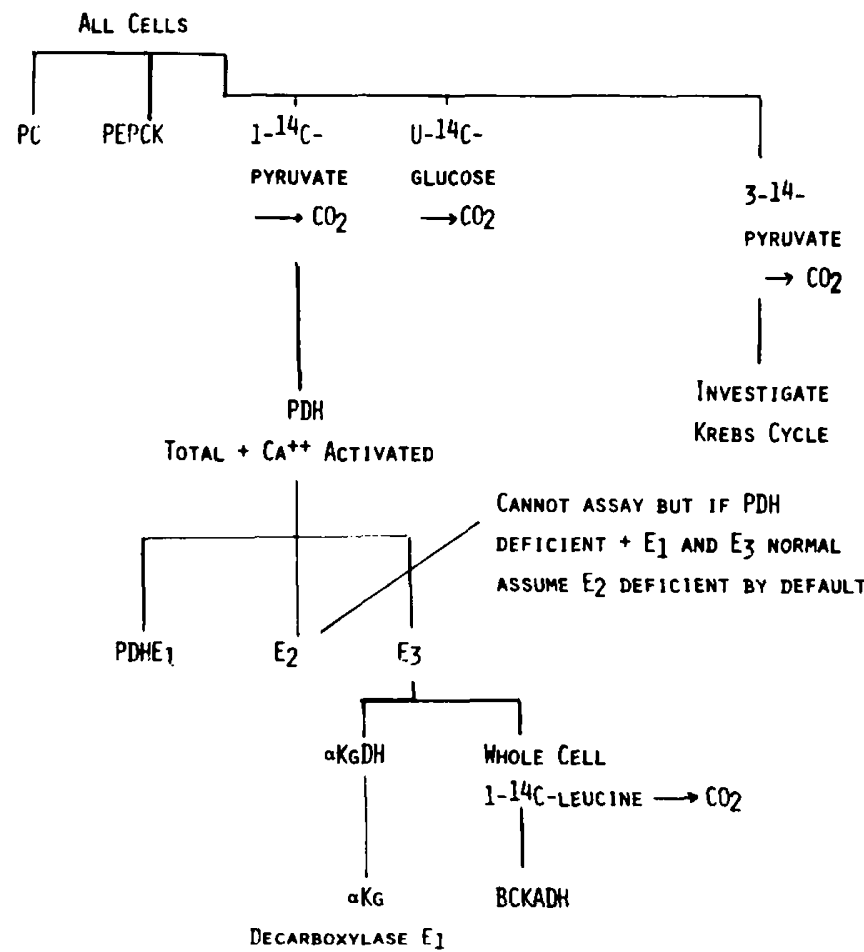

Fig. 2. Flow chart to show sequence of investigations in cultured skin fibroblasts used in this study. PC, pyruvate carboxylase; $\alpha \mathrm{KgDH}, \alpha$ ketoglutarate dehydrogenase; $B C K A D H$, branched-chain keto acid dehydrogenase.
To assess flow through pyruvate dehydrogenase, whole-cell $\left[1-{ }^{14} \mathrm{C}\right]$ pyruvate oxication to ${ }^{14} \mathrm{CO}_{2}$ was measured. Two measurements of pyruvate dehydrogenase activity were made, one of the native activity present in fibroblasts on sonication and another after full activation in the presence of $\mathrm{Ca}^{2+}$. In the event of low pyruvate dehydrogenase activity being found, two of the subcomponents of the complex, $E_{1}$ and $E_{3}$, were measured. If $E_{3}$ was deficient, measurement was also made of branched-chain keto acid dehydrogenase and both the 2-oxoglutarate dehydrogenase and decarboxylase.

Flow from glucose down through glycolysis through pyruvate dehydrogenase and into the Krebs' cycle was assessed by following the oxidation of $\left[U-{ }^{14} \mathrm{C}\right]$ glucose to ${ }^{14} \mathrm{CO}_{2}$. Krebs' cycle flux was assessed by measuring the activity of the cells in oxidising $\left[3-{ }^{14} \mathrm{C}\right]$ pyruvate to ${ }^{14} \mathrm{CO}_{2}$ because two turns of the cycle are required before any label from this moiety is evolved as $\mathrm{CO}_{2}$. A flow chart for these activities is shown below (Fig. 2).

\section{CONTROLS}

Some of these assays show a degree of variability. For instance, the range of values obtained in the pyruvate dehydrogenase assay for cells of control lines vary from 0.3 to $1.2 \mathrm{nmoles} / \mathrm{min} / \mathrm{mg}$ protein for individual assays. This variability arises from three sources: (1) experimental error; (2) changes in enzyme levels due to changing culture conditions, i.e., different batches of fetal calf serum; (3) variability of enzyme level in individual control cell lines. Every assay is carried out in duplicate and is subsequently repeated on different occasions with different control cell lines. For all of the values reported in this study, the activities of different control cell lines in that assay system performed on the same day as the patients are tabulated. We feel that this is probably the only reliable way to compare activities.

\section{RESULTS}

\section{PYRUVATE CARBOXYLASE AND PEPCK}

Measurement of pyruvate carboxylase activity in each of the cell lines tested revealed five cell lines from four different families in which this enzyme was deficient. In all cell lines, the residual activity measured was less than $10 \%$ of the control values obtained (Table 1). In the same table, we also document the pyruvate dehydrogenase activity of these cell lines which were all in the normal range.

Table 1. Pyruvate dehydrogenase (total) and pyruvate carboxylase activities in cultured skin fibroblasts with deficient activity of these enzymes ${ }^{1}$

\begin{tabular}{|c|c|c|c|c|}
\hline \multirow{2}{*}{ Patient } & \multicolumn{2}{|c|}{$\begin{array}{l}\text { Pyruvate dehydrogenase } \\
\text { (nmoles/min/mg protein) }\end{array}$} & \multicolumn{2}{|c|}{$\begin{array}{c}\text { Pyruvate carboxylase } \\
\text { (nmoles/min/mg protein) }\end{array}$} \\
\hline & Patient & Control & Patient & Control \\
\hline \multicolumn{5}{|c|}{ Pyruvate dehydrogenase deficiency } \\
\hline $\left.\begin{array}{l}825 \\
828\end{array}\right\}$ Sibs & $\begin{array}{l}0.085 \pm 0.055^{2}(4)^{3} \\
0.087 \pm 0.021(3) \\
0.060 \pm 0.010(5) \\
0.216 \pm 0.055(9) \\
0.118 \pm 0.015(3) \\
0.145 \pm 0.042(8)\end{array}$ & $\begin{array}{l}0.703 \pm 0.055(4) \\
0.611 \pm 0.089(4) \\
0.758 \pm 0.109(8) \\
0.526 \pm 0.069(9) \\
0.450 \pm 0.064(3) \\
0.592 \pm 0.069(8)\end{array}$ & $\begin{array}{l}0.469 \pm 0.035(2) \\
0.482 \pm 0.119(2) \\
1.910 \pm 0.390(5) \\
0.923 \pm 0.231(3) \\
2.18 \\
1.22 \pm 0.309\end{array}$ & $\begin{array}{r}0.540 \pm 0.084(2) \\
0.580 \pm 0.275(7) \\
1.041 \pm 0.262(5) \\
1.01 \pm 0.047(3) \\
0.622 \quad(1) \\
1.01 \pm 0.480\end{array}$ \\
\hline \multicolumn{5}{|c|}{ Pyruvate carboxylase deficiency } \\
\hline $\left.\begin{array}{l}766 \\
799\end{array}\right\}$ Sibs & $\begin{array}{l}0.338 \pm 0.048(6) \\
0.496 \pm 0.122(2) \\
0.475 \pm 0.054(3) \\
0.560 \pm 0.090(4) \\
0.524 \pm 0.113(3)\end{array}$ & $\begin{array}{l}0.449 \pm 0.032(6) \\
0.514 \pm 0.10(2) \\
0.432 \pm 0.053(3) \\
0.515 \pm 0.046(4) \\
0.481 \pm 0.044(3)\end{array}$ & $\begin{array}{l}0.035 \pm 0.018(6) \\
0.055 \pm 0.022(2) \\
0.045 \pm 0.013(7) \\
0.017 \pm 0.005(4) \\
0.020 \pm 0.011(2)\end{array}$ & $\begin{array}{r}0.776 \pm 0.110(6) \\
0.597 \pm 0.060(2) \\
0.871 \pm 0.202(7) \\
1.09 \pm 0.310(4) \\
0.468 \pm 0.059(2)\end{array}$ \\
\hline
\end{tabular}

' Each determination itself is a mean value obtained in duplicate samples.

${ }^{2}$ Mean \pm S.E.

${ }^{3}$ Numbers in parentheses, number of determinations. 
Measurement of the activity of PEPCK revealed only one cell line which was deficient, where the activity was $17 \%$ of the controls (Table 2). In isolated mitochondria from this patient's fibroblasts, we have shown the activity of PEPCK to be $6 \%$ of normal (23). Normal values of pyruvate carboxylase and dehydrogenase activity were found with this cell line.

\section{PYRUVATE DEHYDROGENASE}

Six cell lines with pyruvate dehydrogenase deficiency were evident in our studies. The amount of activity measurable in pyruvate dehydrogenase varied from 8 to $39 \%$ of the controls in these deficient cell lines (Table 1), and pyruvate carboxylase was normal or greater than normal in all cases.

Further investigation of these cell lines revealed five of them to be deficient in the first subenzyme of the complex, $E_{1}$, and one of them to be deficient in $E_{3}$ with less than normal $E_{1}$ activity (Table $3)$. This latter cell line also had deficient 2-oxoglutarate dehydrogenase (39\% of normal) and branched-chain keto-acid (<5\% of

Table 2. PEPCK activity in cultured skin fibroblasts ${ }^{1}$

\begin{tabular}{lccc}
\hline \multicolumn{1}{c}{ Defect } & $\begin{array}{c}\text { Pa- } \\
\text { tient }\end{array}$ & $\begin{array}{c}\text { Patient (nmoles/ } \\
\text { min/mg protein) }\end{array}$ & $\begin{array}{c}\text { Control (nmoles/ } \\
\text { min/mg protein) }\end{array}$ \\
\hline PEPCK & 585 & $0.283 \pm 0.052^{2}(5)^{3}$ & $1.68 \pm 0.230(5)$ \\
$\begin{array}{c}\text { Pyruvate dehydro- } \\
\text { genase-E }\end{array}$ & 825 & $0.831 \pm 0.219(3)$ & $1.554 \pm 0.797(3)$ \\
$\begin{array}{c}\text { Pyruvate dehydro- } \\
\text { genase-E }\end{array}$ & 584 & $2.21 \pm 0.27(3)$ & $2.02 \pm 0.228(3)$ \\
$\begin{array}{c}\text { Pyruvate carboxyl- } \\
\text { ase }\end{array}$ & 912 & $1.78 \pm 0.31(3)$ & $1.12 \pm 0.367(3)$ \\
\hline
\end{tabular}

'PEPCK was determined according to the method described in Ref. 27.

${ }^{2}$ Mean \pm S.E.

${ }^{3}$ Numbers in parentheses, number of determinations. normal) dehydrogenase. Cell lines with $E_{1}$ pyruvate dehydrogenase deficiencies had normal 2-oxoglutarate dehydrogenase activity.

\section{WHOLE-CELL PYRUVATE OXIDATION}

$\left[1-{ }^{14} \mathrm{C}\right]$ Pyruvate oxidation in whole cells was significantly lower for all cell lines with pyruvate dehydrogenase deficiency $\left(E_{1}\right)$ than in control cell lines (average, $37 \%$ of controls). However, in the case of pyruvate dehydrogenase $\left(E_{3}\right)$ deficiency the rate, although statistically significantly lower, was $75 \%$ of controls. Cell lines with pyruvate carboxylase deficiency did not show reduced rates of $\left[1-{ }^{14} \mathrm{C}\right]$ pyruvate oxidation (Table 4).

$\left[3-{ }^{14} \mathrm{C}\right]$ Pyruvate oxidation was noticeably deficient in all cell lines with pyruvate dehydrogenase deficiency. It was also found to be deficient in two cell lines where $\left[1-{ }^{14} \mathrm{C}\right]$ pyruvate oxidation, and all other enzyme measurements were normal (Table 4). Both of these cell lines were the only lines in which $\left[U-{ }^{14} \mathrm{C}\right]$ glucose $\rightarrow$ ${ }^{14} \mathrm{CO}_{2}$ was found to be deficient. Cell lines with pyruvate dehydrogenase deficiencies showed no marked difference in glucose oxidation rates (Table 5).

\section{SUMMARY OF RESULTS}

The investigation of a total of 40 patients with lactic acidosis yielded five cases of pyruvate carboxylase deficiency, one case of mitochondrial PEPCK deficiency, and two cases with defective $\left[3-{ }^{14} \mathrm{C}\right]$ pyruvate and $\left[U-{ }^{14} \mathrm{C}\right]$ glucose oxidation due to an unknown defect.

\section{DISCUSSION}

\section{PYRUVATE DEHYDROGENASE DEFICIENCY}

Lactic acidemia, either of the chronic or episodic types, presents with a variety of symptoms. Presenting signs may include ataxic episodes, hypoglycemia, optic atrophy, seizures, hypertonia, hep-

Table 3. $E_{1}$ and $E_{3}$ activity in the pyruvate dehydrogenase-deficient cell lines ${ }^{1}$

\begin{tabular}{|c|c|c|c|c|}
\hline \multirow{2}{*}{ Patient } & \multicolumn{2}{|c|}{$\begin{array}{c}\mathbf{E}_{1} \\
\text { (nmoles } / 30 \mathrm{~min} / \mathrm{mg} \text { ) }\end{array}$} & \multicolumn{2}{|c|}{$\begin{array}{c}\mathrm{E}_{3} \\
\text { (nmoles } / \mathrm{min} / \mathrm{mg} \text { ) }\end{array}$} \\
\hline & Patient & Controls & Patient & Controls \\
\hline 825 & $1.64 \pm 0.273^{2}(4)^{3}$ & $4.18 \pm 0.77(4)$ & $11.6 \pm 0.35$ & $8.2 \pm 1.2$ \\
\hline 828 & $0.92 \pm 0.152$ & $4.13 \pm 0.73(4)$ & $7.22 \pm 0.16$ & $8.23 \pm 1.22(2)$ \\
\hline 911 & $1.23 \pm 0.33$ & $5.39 \pm 1.33(3)$ & $6.97 \pm 0.61$ & $8.94 \pm 0.51$ \\
\hline 811 & $1.92 \pm 0.61$ & $4.19 \pm 1.03(5)$ & $7.57 \pm 0.803$ & $7.80 \pm 1.18(3)$ \\
\hline 936 & $0.887 \pm 0.043$ & $6.06 \pm 1.77(3)$ & 6.9 & 11.6 \\
\hline 584 & $1.290 \pm 0.385$ & $3.52 \pm 0.45(3)$ & $0.303 \pm 0.012$ & $9.7 \pm 0.41$ \\
\hline
\end{tabular}

${ }^{1} E_{1}$ and $E_{3}$ activities in cell lines with pyruvate dehydrogenase deficiency were determined as described in "Materials and Methods."

${ }^{2}$ Mean \pm S.D.

${ }^{3}$ Numbers in parentheses, number of determinations.

Table 4. $\left[1-{ }^{14} C\right]$ pyruvate and $\left[3-{ }^{14} C\right] p y r u v a t e$ oxidation in patients with lactic acidosis ${ }^{1}$

\begin{tabular}{|c|c|c|c|c|c|c|}
\hline \multirow{2}{*}{ Defect } & \multirow{2}{*}{ Patient } & \multicolumn{2}{|c|}{$\begin{array}{l}\left.\text { [1- }{ }^{14} \mathrm{C}\right] \text { Pyruvate } \\
\text { (nmoles } / \mathrm{min} / \mathrm{mg} \text { ) }\end{array}$} & \multicolumn{3}{|c|}{$\begin{array}{l}{\left[3-{ }^{14} \mathrm{C}\right] \text { Pyruvate }} \\
\text { (nmoles/hr/mg) }\end{array}$} \\
\hline & & Patient & Controls & Patient & Controls & \\
\hline PDH-E, ${ }_{1}^{2}$ & 825 & $11.6 \pm 1.43^{3}(5)^{4}$ & $20.83 \pm 0.95(5)$ & $0.141 \pm 0.141$ & $4.88 \pm 1.22$ & (4) \\
\hline PDH-E 1 & 828 & $6.01 \pm 1.11$ & $20.83 \pm 0.96(5)$ & $0.930 \pm 0.323$ & $3.31 \pm 0.655$ & (4) \\
\hline PDH-E & 911 & $14.32 \pm 1.74(5)$ & $21.2 \pm 0.80(5)$ & $1.97 \pm 1.117$ & $5.424 \pm 1.240$ & (5) \\
\hline PDH-E & 811 & $8.64 \pm 2.17(5)$ & $21.8 \pm 1.77(5)$ & $0.713 \pm 0.012$ & $4.23 \pm 1.05$ & (3) \\
\hline PDH-E ${ }_{3}$ & 584 & $17.4 \pm 1.3$ & $23.6 \pm 1.98(5)$ & $1.55 \pm 0.85$ & $6.041 \pm 1.89$ & (3) \\
\hline $\begin{array}{l}\text { Pyruvate } \\
\text { carboxylase }\end{array}$ & 912 & $23.6 \pm 4.1$ & $25.3 \pm 5.8$ & 9.76 & 3.35 & (1) \\
\hline Krebs' cycle & 581 & $36.1 \pm 4.4$ & $36.1 \pm 4.3$ & $1.34 \pm 0.346$ & $4.75 \pm 0.77$ & (5) \\
\hline Krebs' cycle & 790 & $32.5 \pm 5.4$ & $36.4 \pm 5.8$ & $0.89 \pm 0.36$ & $6.65 \pm 0.99$ & (4) \\
\hline
\end{tabular}

${ }^{1}$ Assays of whole-cell pyruvate oxidation were carried out as described in "Materials and Methods."

${ }^{2}$ PDH, pyruvate dehydrogenase.

${ }^{3}$ Mean \pm S.E.

${ }^{4}$ Numbers in parentheses, number of determinations. 
atomegaly, delayed neurological development, and failure to thrive. The actual presentation of any one child may involve just one or several of these presenting signs, and these are summarized for each of the patients in which we have found a deficiency (Table 6). There is obvious variability in the patients diagnosed as having pyruvate dehydrogenase- $E_{1}$ deficiency; there is some similarity between patients 825 and 828 (who are sibs) and patient 811 , in that all showed failure to thrive and delayed neurologic development. Patient 911 presented at 18 months with ataxic episodes and seizures, whereas patient 936 died at the age of 16 days with overwhelming acidosis. Most of the cases reported by Blass et al. (4) with pyruvate decarboxylase deficiency were late onset ( 2 to 5 years) cases with intermittent ataxia as a major presenting problem. Patient 911 falls into this category. The early type of presentation of $E_{1}$ deficiency with severe acidosis starting

Table 5. Oxidation rates of $\left[\mathrm{U}^{14}{ }^{14} \mathrm{C}\right]$ glucose to ${ }^{14} \mathrm{CO}_{2}$ in cultured skin fibroblasts ${ }^{1}$

\begin{tabular}{|c|c|c|c|}
\hline \multirow{2}{*}{$\begin{array}{l}\mathrm{Pa}- \\
\text { tient }\end{array}$} & \multirow{2}{*}{ Defect } & \multicolumn{2}{|c|}{$\begin{array}{c}\text { Rate of oxidation } \\
\text { (nmoles } / \mathrm{hr} / \mathrm{mg} / \text { protein) }\end{array}$} \\
\hline & & Patient & Controls \\
\hline 790 & Krebs' cycle & $0.158 \pm 0.075^{2}(7)^{3}$ & $0.917 \pm 0.156(7)$ \\
\hline 581 & Krebs' cycle & $0.195 \pm 0.028(6)$ & $0.716 \pm 0.150(6)$ \\
\hline 584 & $\begin{array}{l}\text { Pyruvate dehydro- } \\
\text { genase- } E_{3}\end{array}$ & $0.609 \pm 0.273(4)$ & $0.440 \pm 0.191(4)$ \\
\hline 811 & $\begin{array}{l}\text { Pyruvate dehydro- } \\
\text { genase } E_{1}\end{array}$ & $1.072 \pm 0.463(4)$ & $0.884 \pm 0.194(4)$ \\
\hline 568 & Unknown & $0.769 \pm 0.164(3)$ & $0.787 \pm 0.191$ \\
\hline 824 & Unknown & $1.27 \pm 0.325$ & $1.04 \pm 0.266(4)$ \\
\hline 862 & Unknown & $1.17 \pm 0.348(4)$ & $1.09 \pm 0.310$ \\
\hline
\end{tabular}

${ }^{1}\left[U .{ }^{14} \mathrm{C}\right] \mathrm{Glucose}$ oxidation was carried out as described in "Materials and Methods."

${ }^{2}$ Mean \pm S.E.

${ }^{3}$ Numbers in parentheses, number of determinations. in the neonatal period is reported by Blass et al. (4) for one case, and similar cases were reported by Stromme et al. (30) and Farrel et al. (12). All have been fatal as was the case in patient 936 and will probably be the outcome in patient 811 . The reasons for the difference between these two types of presentations are not exactly clear. The overall activities in patients 936 and 811 of pyruvate dehydrogenase are somewhat higher than for the other $E_{1}$ deficiencies which does not explain the more acute presentation. None of these pyruvate dehydrogenase- $E_{1}$ deficiency cases have a defect in 2-oxoglutarate dehydrogenase (results not shown). Thus, the fact that the $E_{1}$ enzyme is an $\alpha_{2} \beta_{2}$ subunit tetramer (26) makes it possible that the two types of $E_{1}$ presentation represent a defect in different subunits but there is no experimental evidence to support such an hypothesis at this time.

We have previously reported a case of a male child who died at 7 months with pyruvate dehydrogenase- $E_{3}$ deficiency $(25)$ where the diagnosis was made on postmortem tissue enzyme activity. The case which we have diagnosed here represents the second case we have diagnosed, but this time, the enzyme assays were performed on skin fibroblasts. This patient, like our first, had elevated levels of branched-chain amino acids in the plasma and a deficient 2-oxoglutarate and branched-chain keto acid dehydrogenase activity. The presentation of this case with chronic acidosis, delayed neurological development, failure to thrive, and hypoglycemia was very similar to that reported for the previous patient (25).

\section{PYRUVATE CARBOXYLASE DEFICIENCY}

From the cases in the literature, this deficiency has a somewhat heterogenous phenotype. There appears to be one form of the disease which presents early in life with chronic lacticacidemia, neurologic problems, and fasting hypoglycemia $(1,10,29,35)$ and another which presents between one year and 5 years as degenerative neurological disease resembling Leigh's encephalopathy $(18,31,32)$. The cases we report here fall into the first category having early onset, chronic acidosis, and either seizures or delayed neurologic development. Fasting hypoglycemia is not always ap-

Table 6. Clinical presentation of patients where diagnosis has been made

\begin{tabular}{|c|c|c|c|c|c|c|c|c|c|c|c|}
\hline Patient & Present age & $\begin{array}{l}\text { Typical } \\
\text { lactate } \\
(\mathrm{mM})\end{array}$ & Ataxia & $\begin{array}{c}\text { Tachypnea } \\
\text { acidosis }\end{array}$ & $\begin{array}{c}\text { Fasting } \\
\text { hypoglyce- } \\
\text { mia }\end{array}$ & $\begin{array}{c}\text { Optic } \\
\text { atro- } \\
\text { phy }\end{array}$ & $\begin{array}{l}\text { Hep- } \\
\text { ato- } \\
\text { meg- } \\
\text { aly }\end{array}$ & Seizures & Hypotonia & $\mathrm{DND}^{1}$ & FTT \\
\hline \multicolumn{12}{|c|}{ Pyruvate dehydrogenase } \\
\hline 828 & $28 / 12$ & $\begin{array}{l}3.3 \\
1.4^{2}\end{array}$ & - & Stridor & - & + & - & - & + & + & + \\
\hline 825 & $5 \mathrm{yr}$ & $\begin{array}{l}5.0 \\
2.0^{2}\end{array}$ & - & - & - & + & - & - & $\begin{array}{l}\uparrow \text { Tendon } \\
\text { reflex }\end{array}$ & ++ & ++ \\
\hline 911 & $4^{1 / 2} \mathrm{yr}$ & 2.2 & ++ & - & - & - & - & + & + & - & - \\
\hline 811 & $2 \mathrm{yr}$ & 3.5 & - & ++ & - & - & - & ++ & ++ & ++ & $+t$ \\
\hline 936 & 16 days & 9.0 & - & +++ & - & - & - & - & - & $?$ & - \\
\hline 584 & $2 \mathrm{yr}$ & 8.0 & - & ++ & $+(18)$ & + & + & - & - & ++ & + \\
\hline \multicolumn{12}{|c|}{ Pyruvate carboxylase } \\
\hline 766 & $5 \mathrm{yr}$ & 9.0 & - & ++ & + & - & + & ++ & - & + & - \\
\hline 799 & $5 / 12$ & 11.0 & - & ++ & $+(17)$ & - & - & - & - & + & - \\
\hline 912 & $8 / 12$ & 6.0 & - & ++ & $+(30)$ & - & - & ++ & - & + & + \\
\hline 957 & $15 / 12$ & 6.0 & - & ++ & - & - & - & - & + & + & - \\
\hline 967 & $15 / 12$ & 6.0 & - & ++ & - & - & - & - & + & + & - \\
\hline \multicolumn{12}{|l|}{ PEPCK } \\
\hline 585 & $27 / 12$ & 4.0 & - & - & + & - & + & - & ++ & + & ++ \\
\hline \multicolumn{12}{|c|}{ Krebs' cycle } \\
\hline 581 & $10 \mathrm{yr}$ & 2.0 & + & - & - & - & - & ++ & - & - & - \\
\hline 790 & $12 \mathrm{yr}$ & $\begin{array}{l}8.0 \\
3.0^{2}\end{array}$ & + & + & - & - & - & - & + & + & - \\
\hline
\end{tabular}

${ }^{1}$ DND, delayed neurological development, FTT, failure to thrive.

2 Treated with low-carbohydrate, high-fat diet. 
parent. It is interesting that in the two previously documented cases in which fibroblast studies have been performed to obtain the diagnosis, the presentation has been that of the early onset group $(1,10)$. The low levels of enzyme activity reported here by ourselves and by others in the early onset form of this disease $(1$, $10,29,35)$ are lower than those reported for the later presentation $(29,31,32)$. All of the patients reported here are of North American Indian heritage.

\section{PEPCK}

The presentation of our patient with PEPCK deficiency will be discussed in greater detail in a forthcoming publication (23), but for the purposes of this survey, it is interesting to note the symptoms of hypoglycemia with muscular hypotonia were similar to those reported by Hommes et al. (15). In the case reported by Vidnes and Søvik (36), there was hyperplasia of the endocrine pancreas associated with hypoglycemia and hepatomegaly, and there was the possibility of the observed deficiency of cytosolic PEPCK in the liver being secondary to hyperinsulinism.

\section{DEFICIENT $\left[3-{ }^{14} \mathrm{C}\right]$ PYRUVATE OXIDATION}

Oxidation of $\left[3-{ }^{14} \mathrm{C}\right]$ pyruvate to ${ }^{14} \mathrm{CO}_{2}$ involves the passage of the third carbon of pyruvate through two complete turns of the Krebs' cycle before the ${ }^{14} \mathrm{CO}_{2}$ is released. It is not surprising that cell lines from patients with pyruvate dehydrogenase deficiency therefore have a low rate of $\left[3-{ }^{14} \mathrm{C}\right]$ pyruvate oxidation. However, we have demonstrated two cell lines in which there is a deficiency of $\left[3-{ }^{14} \mathrm{C}\right]$ pyruvate oxidation where there is normal pyruvate dehydrogenase activity and $\left[1-{ }^{14} \mathrm{C}\right]$ pyruvate oxidation. We can only conclude from these observations that these two patients have altered citric acid cycle flux such that either there is a partial blockage of the citric acid cycle or there is significant dilution of the labeled pool of metabolites at some point in the cycle that is only evident in these cells. To our knowledge, no such defect has been previously documented.

The presentation of these patients is rather different in that in one (patient 790) acidosis is a major problem, the lactic acid level is high, and there is ataxia and delayed neurologic development on a chronic basis. In the other case, the lactate is not chronically elevated, and the patient suffers episodic bouts of seizures and ataxia.

The other surprising finding in the cells from these two patients was that the rate of $\left[U_{-}^{14} \mathrm{C}\right]$ glucose metabolism to ${ }^{14} \mathrm{CO}_{2}$ was slower than in controls (Table 6). This parameter in trypsinized skin fibroblasts remains unchanged in patient 811 with pyruvate dehydrogenase- $E_{1}$ deficiency or in patient 584 with pyruvate dehydrogenase $E_{3}$ deficiency. The interpretation of this finding is difficult because, although the rate of pyruvate oxidation is almost the same in trypsinized and nontrypsinized cells, the rate of glucose oxidation is much lower in trypsinized cells (unpublished observation). Borud and Stromme (7) showed that a cell line defective in pyruvate dehydrogenase- $\mathrm{E}_{1}$ activity oxidized $\left[\mathrm{U}_{-}{ }^{14} \mathrm{C}\right]$ glucose to ${ }^{14} \mathrm{CO}_{2}$ at a rate of $60 \%$ that of control cells. We have found that the inability of the two cell lines to oxidize $\left[U_{-}{ }^{14} \mathrm{C}\right]$ glucose to ${ }^{14} \mathrm{CO}_{2}$ at appropriate rates further reflects the disturbance that must be affecting Krebs' cycle flux. Inability to properly oxidize pyruvate fully to $\mathrm{CO}_{2}$ and water in the tissues of these patients must lead in some way to a decreased overall turnover of pyruvate. Why this is not reflected in $\left[1-{ }^{14} \mathrm{C}\right]$ pyruvate oxidation is a matter for further investigation and should increase our knowledge not only of Krebs' cycle control mechanisms but also of the problem in these two patients.

\section{CONCLUSIONS}

From a total of 40 patients with lactic acidosis, we have been able to identify the precise location of the enzymic deficit in 12 and tentatively identify the area in which the deficit is located in an additional two of these patients. This leaves a rather large number of patients, 28 , in which we cannot find the underlying deficiency. Our failure to do so may stem from three basic reasons: (1) the enzyme deficiency may not be well expressed in fibroblasts, e.g., cytosolic PEPCK; (2) the deficiency may be expressed in fibroblasts, but our tests are not sensitive enough to measure it, e.g. pyruvate dehydrogenase phosphatase; (3) the lactic acidosis may be a secondary phenomenon resulting from a primary block elsewhere in metabolism, e.g., fatty acid or branched-chain amino acid oxidation. We are actively searching for new ways to probe cell lines for which we can demonstrate no defect and are confident that our screening system can be made more comprehensive with the addition of further tests. Only when the root cause of lactic acidosis in all of the patients studied has been found can we hope to devise a comprehensive approach to this problem.

\section{REFERENCES AND NOTES}

1. Atkin. B. M., Utter, M. F., and Weinberg, M. B.: Pyruvate carboxylase and phosphoenolpyruvate carboxykinase activity in leukocytes and fibroblasts from a patient with pyruvate carboxylase deficiency. Pediatr. Res.. 13: 38 (1979).

2. Ballard, F. J., and Hanson, R. W.: Phosphoenolpyruvate carboxykinase and pyruvate carboxylase in developing rat liver. Biochem. J., 104: 866 (1967)

3. Blass. J. P.. Avigan, J., and Uhlendorf, B. W.: A defect in pyruvate decarboxylase in a child with an intermittent movement disorder. J. Clin. Invest., 49: 423 (1970).

4. Blass, J. P., Cederbaum, S. D., and Gibson, S. E.: Clinical and metabolic abnormalities accompanying deficiencies in pyruvate oxidation. In: F. A. Hommes, C. J. Van den Berg: Normal and Pathological Development of Energy Metabolism. pp. 193-210 (Academic Press, Inc., New York, 1975).

5. Blass, J. P., Kark, R. A. P., and Engel, W. K.: Clinical studies of a patient with pyruvate decarboxylase deficiency. Arch. Neurol., 25: 449 (1971).

6. Blass, J. P.. Lonsdale, D., Uhlendorf. B. W., and Ham. E.: Intermittent ataxia with pyruvate decarboxylase activity. Lancet, 1: 1302 (1971).

7. Borud. O., and Stromme. J. H.: Metabolic studies on normal and pyruvate dehydrogenase deficient cultured human fibroblasts. Scand. J. Clin. Lab. Invest., 37: 419 (1977)

8. Cederbaum, C. D., Blass, J. P., Minkofr, N., Brown, W. J., Cotton, M. E., and Harris, S. H.: Sensitivity to carbohydrate in a patient with familial intermittent lactic acidosis and pyruvate dehydrogenase deficiency. Pediatr. Res.. 10: 713 (1976).

9. Denton, R. M.. Randle, P. J., Bridges, B. J.. Cooper. R. H., Kirby, A. C., Pask. H. T., Severson, D. L., Stansbie, D., and Whitehouse, G.: Regulation of mammalian pyruvate dehydrogenases. Mol. Cell. Biochem., 9: 27 (1975).

10. De Vivo, D., Haymond. M. W., Leckie, M. P., Bussman, Y. L., McDougal. D. B., and Paglara, A. S.: Clinical and biochemical implications of pyruvate carboxylase deficiency. J. Clin. Endocrinol. Metab., 45: 1281 (1977).

11. Farmer, T. W., Veath, L., Miller, A. L., O'Brien, J. S., and Rosenberg, R. H.: Pyruvate decarboxylase deficiency in a patient with subacute necrotising encephalomyelopathy. Neurology. 23: 429 (1973).

12. Farrel, D. F., Clark, A. F., Scott, C. R., and Wennberg. R. P.: Absent pyruvate decarboxylase in man. A cause of congenital lacticacidosis. Science (Wash. D C.). 187: 1082 (1975).

13. Fiser, R. H., Jr., Melsher, H. L., and Fisher, D. A.: Hepatic phosphoenolpyruvate carboxylase (PEPCK) deficiency. A new cause of hypoglycemia in childhood. Pediatr. Res., 10: 60 (1974).

14. Haworth, J. C., Perry, T. L., Blass, J. P.. Hansen, G.. and Urquhart. N.: Lactic acidosis in three sibs due to defects in both pyruvate dehydrogenase and $\alpha$ ketoglutarate dehydrogenase complexes. Pediatrics, 58 : 564 (1976).

15. Hommes. F. A., Bendien, K.. Elema. J. D., Bremer, H. J., and Lombeck, 1.: Two cases of phosphoenolpyruvate carboxykinase deficiency. Acta Paediatr. Scand., 65: 233 (1976).

16. Howell, R. R.. Ashton, D. M.. and Wyngaarden, J. B.: Glucose-6-phosphatase deficiency glycogen storage disease. Studies on the interrelationships of carbohydrate. lipid, and purine abnormalities. Pediatrics, 29: 553 (1962).

17. Lowe, C. U., Sokal, J. E.. Moscovich, L. L.. Sancione, E. J.. and Doray. B. H.: Studies in liver glycogen disease. Effects of glucagon and other agents on metabolic pattern and clinical status. Am. J. Med., 3.3: 4 (1962).

18. Maesaka, H., Komiya. K., Nisugi, K., and Tada, K.: Hyperalaninemia, hyperpyruvicemia and lactic acidosis due to pyruvate carboxylase deficiency of the liver. Treatment with thiamine and lipoic acid. Eur. J. Pediatr., 122: 159 (1976).

19. Melancon, S. B., Dallaire, L., and Potier, M.: Lipoamide dehydrogenase in cultured human skin fibroblasts. Clin. Chim. Acta, 87: 29 (1978).

20. Melancon, S. B., Khachadurian, A. K., Nadler. H. L., and Brown. B. I.: Metabolic and biochemical studies in fructose 1,6-diphosphatase deficiency. J. Pediatr. 82: 650 (1973).

21. Pagliara, A. S., Karl, I. E., Keating. J. P., Brown, B. I., and Kipnis, D. M.: Hepatic fructose 1,6-diphosphatase deficiency. J. Clin. Invest.. 51: 2115 (1972).

22. Reed, L. J., and Wilms, C. R.: Purification and resolution of the pyruvate dehydrogenase complex. Methods Enzymol.. 9: 247 (1966).

23. Robinson, B. H., Kahler. S., and Taylor, J.: Mitochondrial phosphoenolpyruvate carboxykinase deficiency in a child with lacticacidemia, hypotonia, and failure to thrive. Abstract to American Society of Human Genetics Meeting. Minneapolis, MN, Oct. 1979.

24. Robinson, B. H., and Sherwood, W. G.: Pyruvate dehydrogenase phosphatase deficiency: a cause of congenital lactic acidosis in infancy. Pediatr. Res.. 9: 935 (1975). 
25. Robinson, B. H., Taylor, J., and Sherwood, W. G.: Deficiency of dihydrolipoyl dehydrogenase (a component of the pyruvate and $\alpha$-ketoglutarate dehydrogenase complexes): a cause of congenital chronic lactic acidosis in infancy. Pediatr. Res., 11: 1198 (1977).

26. Roche, T. E., and Reed, L. J.: Function of the nonidentical subunits of mam malian pyruvate dehydrogenase. Biochem. Biophys. Res. Commun., 48: 840 (1972).

27. Roobol, A. E., and Alleyne, G. A. O.: Regulation of renal gluconeogenesis by calcium ions, hormones and adenosine cyclic $3^{\prime} 5^{\prime}$-monophosphate. Biochem. J., 134: 157 (1973)

28. Rudiger, H. W., Langenbeck, U., Schulze-Scheneking. M., Goedde, H. W., and Schuchmann, L.: Defective decarboxylase in branched-chain keto acid oxidase multi-enzyme complex in classical types of maple syrup urine disease. Humangenetic, 14: 257 (1972).

29. Saudubray, J. M.. Marsac, C., Charpentier, C., Cathelineau, L., Besson-Leaud, M., and Leroux, J. P.: Neonatal congenital lactic acidosis with pyruvate carboxylase deficiency in two s:blings. Acta Paediatr. Scand., 65: 717 (1976).

30. Stromme, J. H., Borud, O., and Moe, P. J.: Fatal lactic acidosis in a newborn attributable to a congenital defect of pyruvate dehydrogenase. Pediatr. Res., 10: 60 (1976).

31. Tada, K., Takada, G. Omura, K., and Itokawa, Y.: Congenital lactic acidosis due to pyruvate carboxylase deficiency: absence of an inhibitor of TPP-ATP phosphoryl transferase. Eur. J. Pediatr.. 127: 141 (1978).

32. Tang. T. T., Good, T. A., Dyken, P. R., Johnsen. S. D., McCreadie, S. R., Sy, S T., Lardy, H. A., and Rudolph, F. D.: Pathogenesis of Leigh's encephalomyelopathy. J. Pediatr., 81: 189 (1972).

33. Taylor, S. I., Mukherjee, C., and Jungas, R. L.: Studies on the mechanism of activation of adipose tissue pyruvate dehydrogenase by insulin. J. Biol. Chem. 248: 73 (1973)

34. Van Biervliet, J. P. G. M., Bruinvis, L., Ketting, D., DeBrue, P. K., Van der Heiden, C., Wadman. J. L., Bookelman, W. H., and Van Haest, U.: Hereditary mitochondrial myopathy with lacticacidemia; A De-Toni-Fanconi-Debre Syn- drome and a defective respiratory chain in voluntary striated muscles. Pediatr. Res., 11: 1088 (1977).

35. Van Biervliet, J. P. G. M., Bruinvis, L., van der Heiden, C., Ketting, D., Wadman S. K., Willemse, J. L., and Monnens, L. A. H.: Report of a patient with severe chronic lactic acidemia and pyruvate carboxylase deficiency. Dev. Med. Child. Neurol., 19: 392 (1977).

36. Vidnes, J., and Søvik, O.: Gluconeogenesis in infancy and childhood. III Deficiency of the extramitochondrial form of hepatic phosphoenolpyruvate carboxykinase in a case of persistent neonatal hypoglycaemia. Acta Paediatr. Scand., 65: 307 (1976)

37. Weiland, O. H., Seiss, E. A., Weiss, L., Lomer, G., Patzelt, C., Portenhauser, R. Hartmann, J., and Schirmann, A.: Regulation of the mammalian pyruvate dehydrogenase complex by covalent modification. Symp. Soc. Exp. Biol., 27: 371 (1973).

38. Willems, J. L., Monnens, L. A. H., Trijbils, J. M. F., Veerkamp, J. H., Myer, A E. F. H., Van Dam, K., and Van Haest, U.: Leigh's encephalomyelopathy in a patient with cytochrome $c$ oxidase deficiency in muscle tissue. Pediatrics, 60: 850 (1977)

39. Note added by author, November 6, 1979: Two patients out of the group of 28 unidentified patients have been subsequently shown by us to have biotinresponsive triple carboxylase deficiency. Pyruvate carboxylase shows normal activity in cells from these patients unless grown in biotin-deficient medium.

40. The authors thank the medical Research Council of Canada for their financial support of this work. We also thank the individual pediatricians from North America and Europe who have sent fibroblast cultures on their patients with lacticacidosis for us to study.

41. Requests for reprints should be addressed to: Dr. Brian H. Robinson, Research Institute, The Hospital for Sick Children, 555 University Avenue. Toronto, Ontario, M5G IX8, Canada.

42. Received for publication September 17, 1979.

43. Accepted for publication November 29, 1979. 